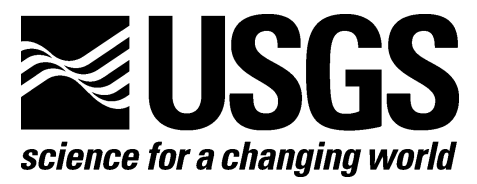

\title{
A Review of Land-Cover Mapping Activities in Coastal
}

\section{Alabama and Mississippi}

By Kathryn E.L. Smith, Amar Nayegandhi, and John C. Brock

Open-File Report 2009-1028

U.S. Department of the Interior

U.S. Geological Survey 


\section{U.S. Department of the Interior KEN SALAZAR, Secretary}

\section{U.S. Geological Survey \\ Suzette M. Kimball, Acting Director}

\section{U.S. Geological Survey, Reston, Virginia: 2009}

For product and ordering information:

World Wide Web: http://www.usgs.gov/pubprod

Telephone: 1-888-ASK-USGS

For more information on the USGS - the Federal source for science about the Earth, its natural and living resources, natural hazards, and the environment:

World Wide Web: http://www.usgs.gov

Telephone: 1-888-ASK-USGS

Suggested citation:

Smith, K.E.L.., Nayegandhi, Amar, Brock, J.C., 2009, A review of land-cover mapping activities in coastal Alabama and Mississippi: St. Petersburg, FL, U.S. Geological Survey Open-File Report 2009-1028, 19p.

Any use of trade, product, or firm names is for descriptive purposes only and does not imply endorsement by the U.S. Government.

Although this report is in the public domain, permission must be secured from the individual copyright owners to reproduce any copyrighted material contained within this report. 


\section{Contents}

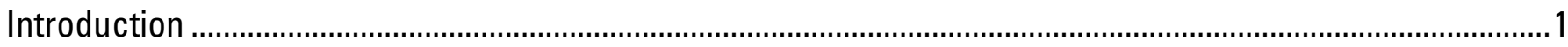

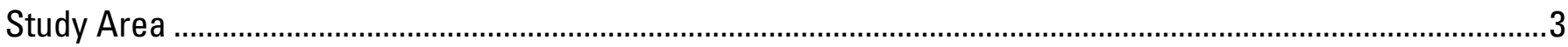

High-Resolution Imagery Sources .................................................................................................................

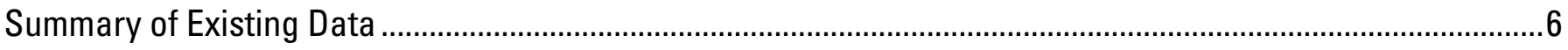

High-Resolution LULC Data .............................................................................................................

Moderate-Resolution LULC Data ...................................................................................................

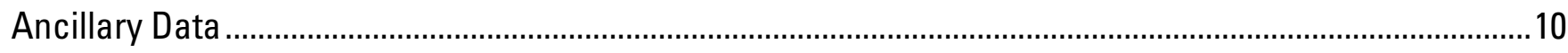

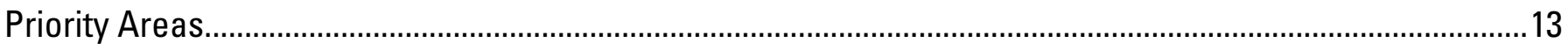

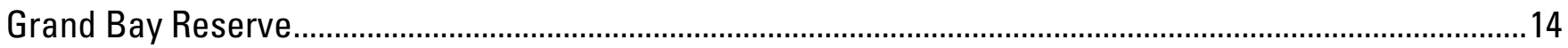

Gulf Islands National Seashore ..............................................................................................................

City of Mobile

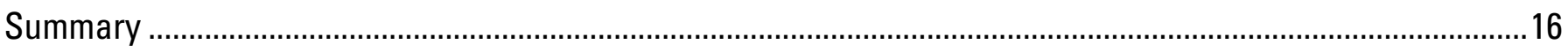

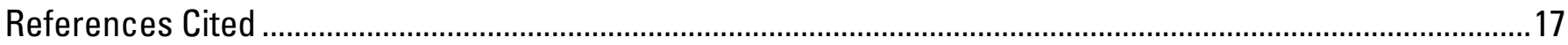

Appendix A: Grand Bay National Estuarine Research Reserve 2002 Habitat Map Vegetation Class

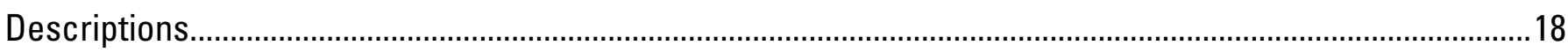

\section{Figures}

1. Annotated satellite image of the coastal region of Mississippi and Alabama located within the Northern Gulf of Mexico (NGOM) Ecocystem Change and Hazard Susceptibility Project boundary area...........4 
2. A map of the coverage of DigitalGlobe's QuickBird satellite imagery for the years 2005 through August

2008 for the coastal Alabama and Mississippi study area...................................................................

3. Map showing the 2002 Grand Bay National Estuarine Research Reserve (GBNERR) habitat dataset, which was derived from high-resolution QuickBird imagery .................................................................

4. Map showing National Oceanic and Atmospheric Administration (NOAA) Coastal-Change and Analysis Program (C-CAP) 2006 post-Hurricane Katrina data coverage for the Alabama and Mississippi study

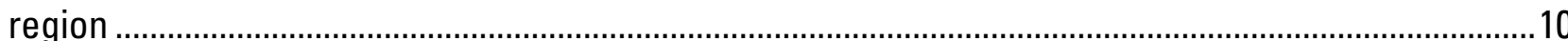

\section{Tables}

1. Land-use and land-cover (LULC) and ancillary data for the State of Alabama 12

2. Land-use and land-cover (LULC) and ancillary data for the State of Mississippi 13 


\title{
A Review of Land-Cover Mapping Activities in Coastal
}

\section{Alabama and Mississippi}

\author{
By Kathryn E.L. Smith, Amar Nayegandhi, and John C. Brock
}

\section{Introduction}

Land-use and land-cover (LULC) data provide important information for environmental management. Data pertaining to land-cover and land-management activities are a common requirement for spatial analyses, such as watershed modeling, climate change, and hazard assessment. In coastal areas, land development, storms, and shoreline modification amplify the need for frequent and detailed land-cover datasets. The northern Gulf of Mexico coastal area is no exception. The impact of severe storms, increases in urban area, dramatic changes in land cover, and loss of coastal-wetland habitat all indicate a vital need for reliable and comparable land-cover data.

Four main attributes define a land-cover dataset: the date/time of data collection, the spatial resolution, the type of classification, and the source data. The source data are the foundation dataset used to generate LULC classification and are typically remotely sensed data, such as aerial photography or satellite imagery. These source data have a large influence on the final LULC data product, so much so that one can classify LULC datasets into two general groups: LULC data derived from aerial photography and LULC data derived from satellite imagery. The final LULC data can be converted from one format to another (for instance, vector LULC data can be converted into raster data for analysis purposes, and vice versa), but each subsequent dataset maintains the imprint of the source 
medium within its spatial accuracy and data features. The source data will also influence the spatial and temporal resolution, as well as the type of classification.

The intended application of the LULC data typically defines the type of source data and methodology, with satellite imagery being selected for large landscapes (state-wide, national data products) and repeatability (environmental monitoring and change analysis). The coarse spatial scale and lack of refined land-use categories are typical drawbacks to satellite-based land-use classifications. Aerial photography is typically selected for smaller landscapes (watershed-basin scale), for greater definition of the land-use categories, and for increased spatial resolution. Disadvantages of using photography include time-consuming digitization, high costs for imagery collection, and lack of seasonal data. Recently, the availability of high-resolution satellite imagery has generated a new category of LULC data product. These new datasets have similar strengths to the aerial-photo-based LULC in that they possess the potential for refined definition of land-use categories and increased spatial resolution but also have the benefit of satellite-based classifications, such as repeatability for change analysis. LULC classification based on high-resolution satellite imagery is still in the early stages of development but merits greater attention because environmental-monitoring and landscapemodeling programs rely heavily on LULC data.

This publication summarizes land-use and land-cover mapping activities for Alabama and Mississippi coastal areas within the U.S. Geological Survey (USGS) Northern Gulf of Mexico (NGOM) Ecosystem Change and Hazard Susceptibility Project boundaries. Existing LULC datasets will be described, as well as imagery data sources and ancillary data that may provide ground-truth or satellite training data for a forthcoming land-cover classification. Finally, potential areas for a high-resolution land-cover classification in the Alabama-Mississippi region will be identified. 


\section{Study Area}

The USGS NGOM project area includes the coastal areas of Alabama, Mississippi, and Louisiana. The project boundaries were established using a combination of watershed and State boundary lines. The Louisiana coastal area has numerous ongoing habitat-mapping and monitoring programs, so the focus of this summary is to assess the Alabama and Mississippi region of the NGOM study area (fig. 1). This region will be identified as the AL-MS study region.

The land-cover characteristics of the AL-MS study region are diverse, with a mix of urban areas, suburban communities, agriculture, and industry. Mobile, AL, is the only high-intensity urban area, but coastal communities run almost the entire length of the coastline. There are numerous natural areas designated through State and Federal programs, including Mississippi Coastal Preserves, Grand Bay National Estuarine Research Reserve (GBNERR), Grand Bay National Wildlife Refuge, Gulf Islands National Seashore, and Bon Secour Wildlife Refuge. These are areas with potential for high-resolution land-cover mapping products geared toward habitat mapping or monitoring. Potential partners include the U.S. Fish and Wildlife Service (FWS), the Mississippi Department of Marine Resources, and the Alabama Department of Conservation and Natural Resources.

High-resolution mapping of urban areas could include portions of the cities of Gulfport, Biloxi, Mobile, AL, and Pascagoula, MS. All of these cities are large population centers and have highly dynamic coastal development that may benefit from high-resolution mapping. Potential partners include city planning departments, emergency response agencies, the South Alabama Regional Planning Commission, and the Southern Mississippi Planning and Development District, as well as Federal partners. 


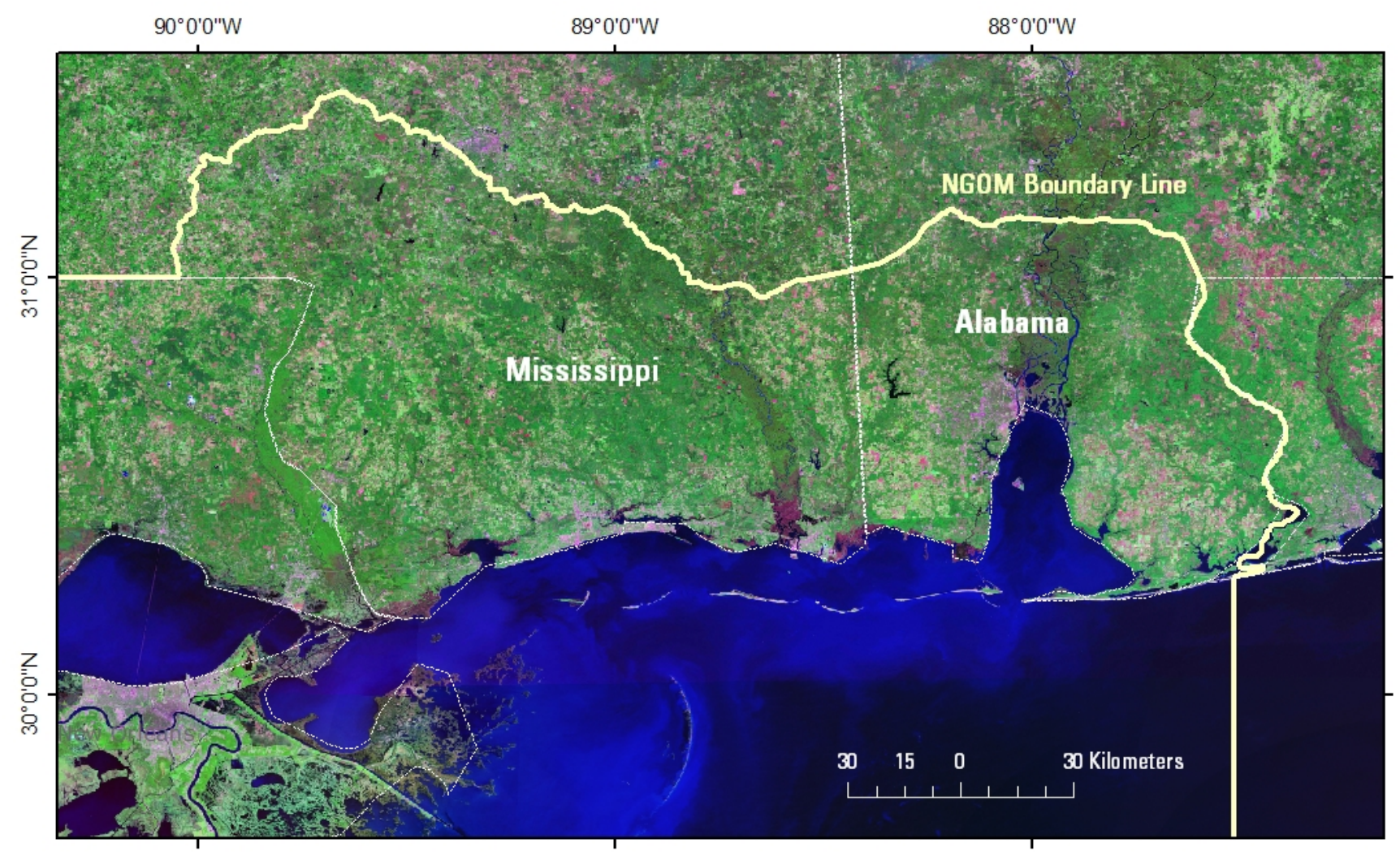

Figure 1. The coastal region of Alabama and Mississippi located within the Northern Gulf of Mexico (NGOM) Ecosystem Change and Hazard Susceptibility Project boundary area.

\section{High-Resolution Imagery Sources}

High-resolution satellite imagery is typically distinguished as satellite imagery having a geometric (spatial) resolution of less then 5 meters (Fritz, 1996). Most high-resolution satellite imagery is available through the commercial sector; therefore, use of the imagery can be expensive. Also, since datasets have large file sizes and weather conditions limit the quality of collected data, the data are not acquired at regular time intervals. Instead, the satellites have to be directed to collect imagery at specific locations and times. This characteristic can be a disadvantage, because tasking a satellite is costly, and existing data for a specific area may be limited. But projects that require specific collection parameters, 
such as mapping water quality or vegetation patterns using high-resolution imagery, may find the ability to train the satellite to meet those objectives an advantage over traditional preset imagery collection.

Two high-resolution imagery satellites were selected as potential sources of useful data for the high-resolution LULC mapping study within the AL-MS study region: IKONOS and QuickBird. IKONOS was launched in 1999 and produces both multi-spectral (spatial resolution of $3.2 \mathrm{~m}$ ) and panchromatic ( 82 centimeters) high-resolution data products. To determine data availability, a technical service request with a specific area of interest is made to the operating company.

QuickBird was launched in 2001 and obtains multispectral imagery at 2.4-2.8 m and panchromatic imagery at 60-70 cm. Google Earth (http://earth.google.com/) and the DigitalGlobe Web sites (http://www.digitalglobe.com/) have DigitalGlobe coverage layers and previews, making it simple to access their imagery holdings for project study areas. Post-2005 image availability is extensive throughout the AL-MS study area (fig. 2).

In addition, WorldView-1 and GeoEye-1 satellites, launched in September 2007 and September 2008, respectively, have 50-cm spatial resolution and may provide useful data in future project proposals but lack historical coverage. Both IKONOS and GeoEye-1 are operated by GeoEye (http://www.geoeye.com/). WorldView-1 and Quickbird are operated by DigitalGlobe.

The Commercial Remote Sensing Space Policy (CRSSP, http://crssp.usgs.gov/) (Office of Science and Technology, 2003) was implemented by the USGS in partnership with National Oceanic and Atmospheric Administration (NOAA). The objectives are to (1) collect near-term land remote sensing data requirements of U.S. Federal civil agencies and provide query/report capabilities to help agencies leverage resources in areas of common interest, (2) provide documented evidence for potential remote sensing funding initiatives, (3) satisfy user requirements with existing data sources where possible, and (4) provide the commercial satellite and aerial industry with a snapshot of civil agency needs, allowing industry an opportunity to respond with accurate and specific data and services. To 
meet these objectives, the USGS has created the CRSSP Imagery-Derived Requirements (CIDR) Entry Tool (http://cidr.cr.usgs.gov/) where Federal agencies can enter their data requirements, review existing requirements, and explore potential data partnerships.

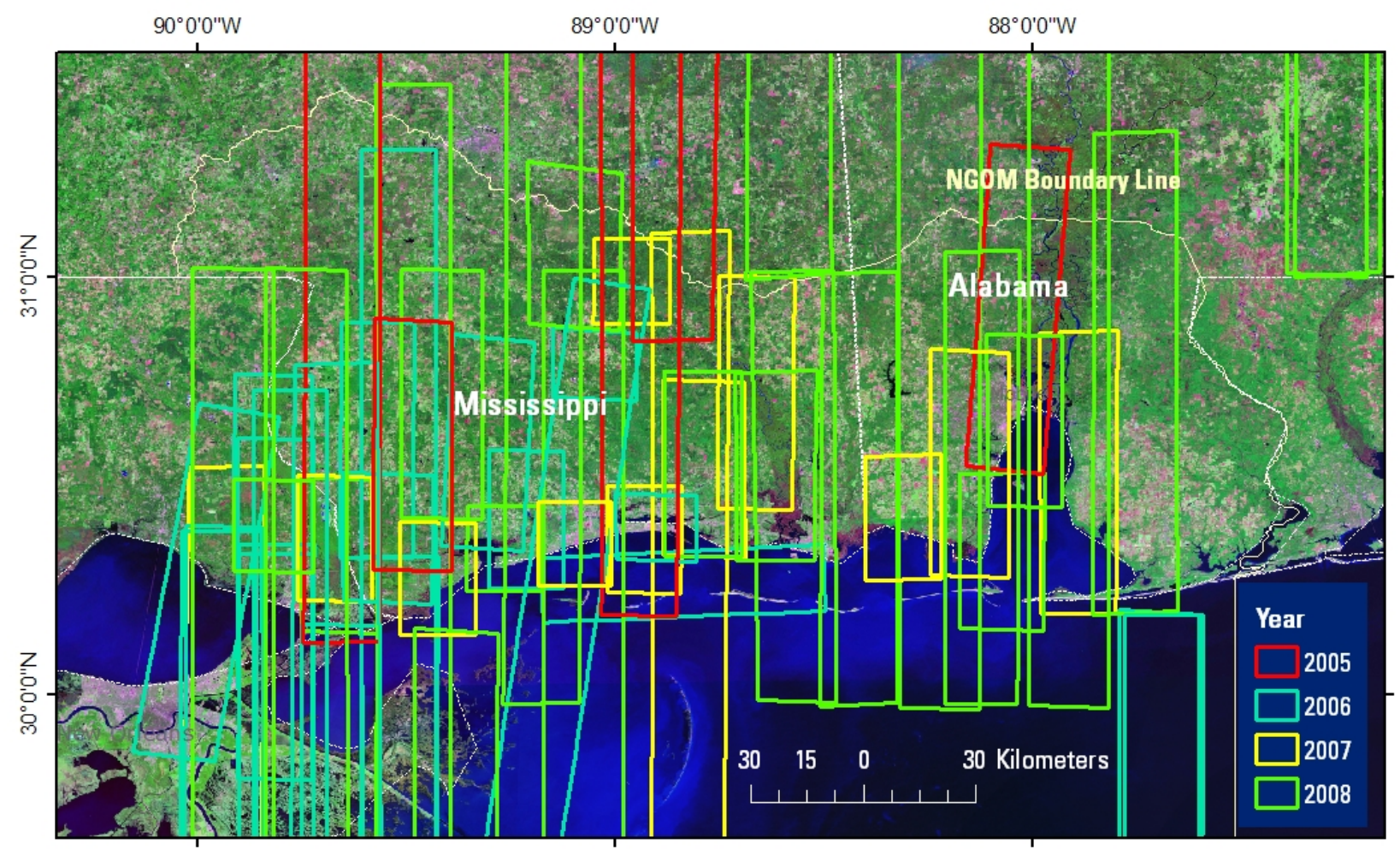

Figure 2. A map of the coverage of DigitalGlobe's QuickBird satellite imagery for the years 2005 through August 2008 for the coastal Alabama and Mississippi region. Extensive coverage of the study area was made in 2008. NGOM, Northern Gulf of Mexico Ecosystem Change and Hazard Susceptibility Project.

\section{Summary of Existing Data}

Determining existing geospatial datasets for a large region is difficult due to the multiple government and private entities that may be responsible for conducting such projects at both the large and small scales. It becomes particularly difficult when the goal is to locate products derived from high- 
resolution imagery, because these study regions tend to be small in area and lack the broad-scale distribution and notification of large-scale LULC data products. However, an assessment of the current available datasets is useful for the planning process, and therefore high-resolution, moderate-resolution, and ancillary datasets were identified for the AL-MS study region (tables 1 and 2).

\section{High-Resolution LULC Data}

Existing high-resolution LULC data within the AL-MS study region are minimal, with only one dataset being identified within the entire region. The dataset was created for the Grand Bay National Estuarine Research Reserve (GBNERR) from 2002 QuickBird imagery (fig. 3). The purpose of the dataset was to provide a habitat map for the GBNERR and surrounding area. The product was created by the Gulf Coast Geospatial Center (GCGC) using an ISODATA clustering algorithm in the ERDAS Imagine (http://www.erdas.com) software package (GCGC, unpub. data, 2007). Fourteen classes were identified: beach/exposed sand, freshwater marsh/aquatic vegetation, high marsh, industrial facilities, intermediate marsh, roads/driveways, salt pan, scrub/shrub/saplings, tidal/inundated marsh, forest/trees, upland grasses/agriculture/residential, water, wet herbaceous, and "unclassified" (appendix A). The

GCGC also produced a fire-fuel model for Mississippi Sandhill Crane National Wildlife Refuge based on 2002 QuickBird imagery. 


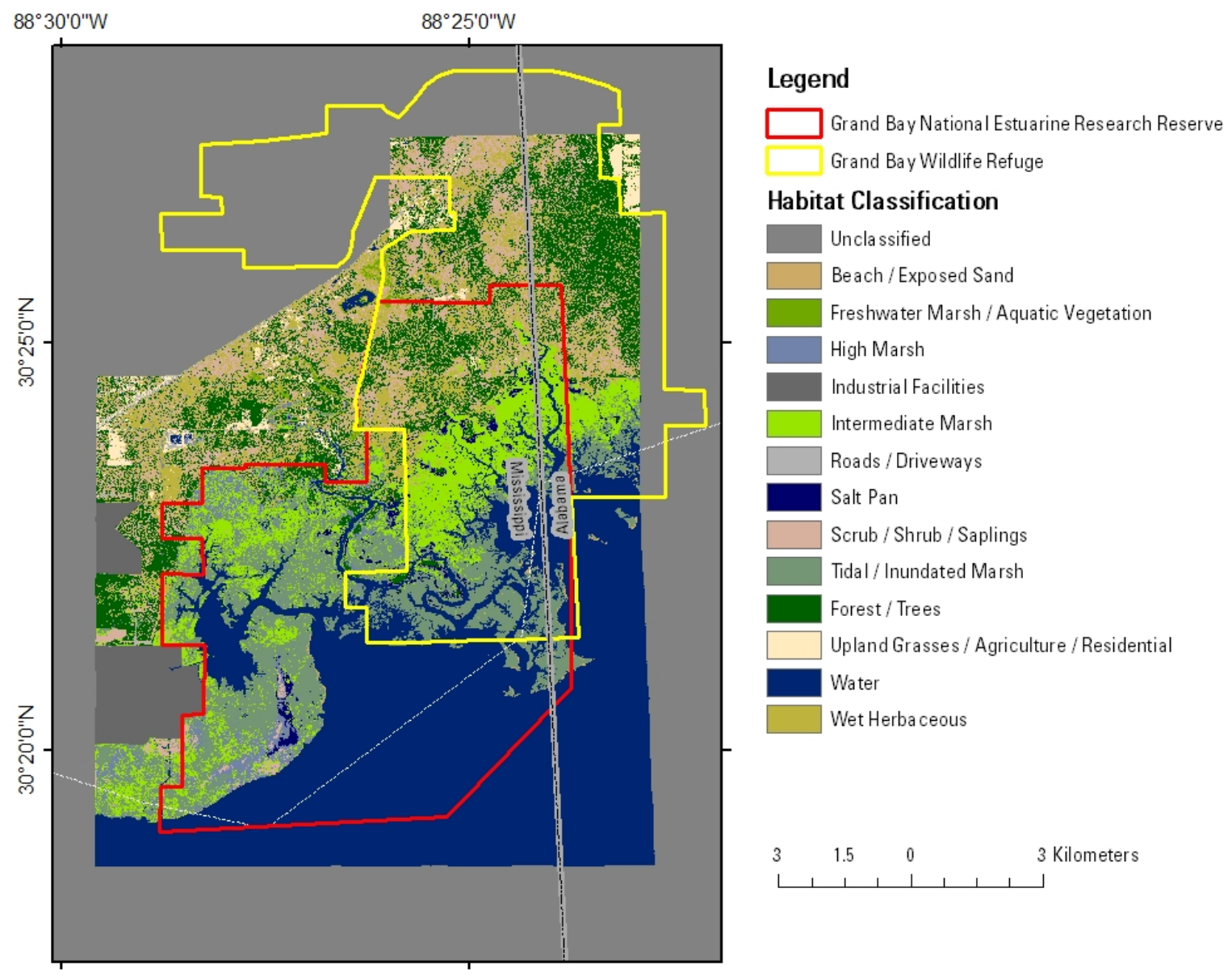

Figure 3. The 2002 Grand Bay National Estuarine Research Reserve (GBNERR) habitat dataset was derived from high-resolution QuickBird imagery. Data provided by GBNERR.

\section{Moderate-Resolution LULC Data}

Traditional LULC datasets are derived from Landsat sensors: Multispectral Scanner (MSS), Thematic Mapper (TM), and Enhanced Thematic Mapper Plus (ETM+). Landsat imagery has been collected since the 1970s and provides by far the greatest temporal and spatially consistent satellite imagery record of the United States. The Multi-Resolution Land Characteristics (MRLC) Consortium generates the National Land Cover Dataset (NLCD) approximately every 10 years, with existing datasets for 1992 and 2001 (http://www.mrlc.gov/). As a member of the MRLC, the NOAA Coastal- 
Change Analysis Program (C-CAP) is responsible for mapping the coastal regions of the United States. The NOAA program chooses to update the dataset every 5 years, rather than the 10 years of the NLCD. The entire AL-MS study region falls within the NOAA mapping program and is updated every 5 years, increasing the number of moderate-resolution land-cover datasets for this region to three: 1996, 2001, and 2005. NOAA does not include the 1992 dataset within the C-CAP LULC datasets because of inconsistencies in the methodology and classification scheme with post-1992 datasets, thereby making change analysis and comparative studies difficult. A fourth dataset, post-Hurricane Katrina 2006 LULC, was created for most of the AL-MS study region, excepting a small portion of the eastern AlabamaFlorida border (fig. 4).

Additional moderate-resolution LULC datasets were created by the Mississippi Department of Transportation (MSDOT) for 1990 and 2000 for the I-10 highway, which runs east-west, parallel to the Gulf of Mexico coastline (Johnson and others, 2002). These data would have provided additional LULC datasets for the Mississippi coastal counties, but the datasets have been lost and could not be obtained from the researching parties (D. Truax, Department of Civil and Environmental Engineering, Mississippi State University, written commun., August 21, 2008). In addition, the Mississippi Automated Resources Information System (MARIS) has several LULC datasets, one derived from historic aerial photography (1972-75) and others from Landsat data (1993, 1999, and 2003). The 1993 and 2003 data are statewide, whereas the 1999 data are for coastal Mississippi counties only. The MARIS historic LULC dataset may be the same nationwide dataset published by the USGS, but we are uncertain because detailed metadata were not obtained.

The Mississippi Department of Environmental Quality (MSDEQ), Office of Geology, conducted a report on Mississippi coastal geology, which included an LULC change analysis (Meyer-Arendt and Yassin, 1994). The MSDEQ digitized Fish and Wildlife Service maps from 1956 and 1978-82. They then digitized LULC data from 1992 aerial photography and conducted a change analysis for these three 
dates (Meyer-Arendt and Yassin, 1994; Oivanki and others, 1995). These geospatial datasets are available on the MSDEQ Web site (http://geology.deq.state.ms.us/coastal/infomaps-landuse.htm).

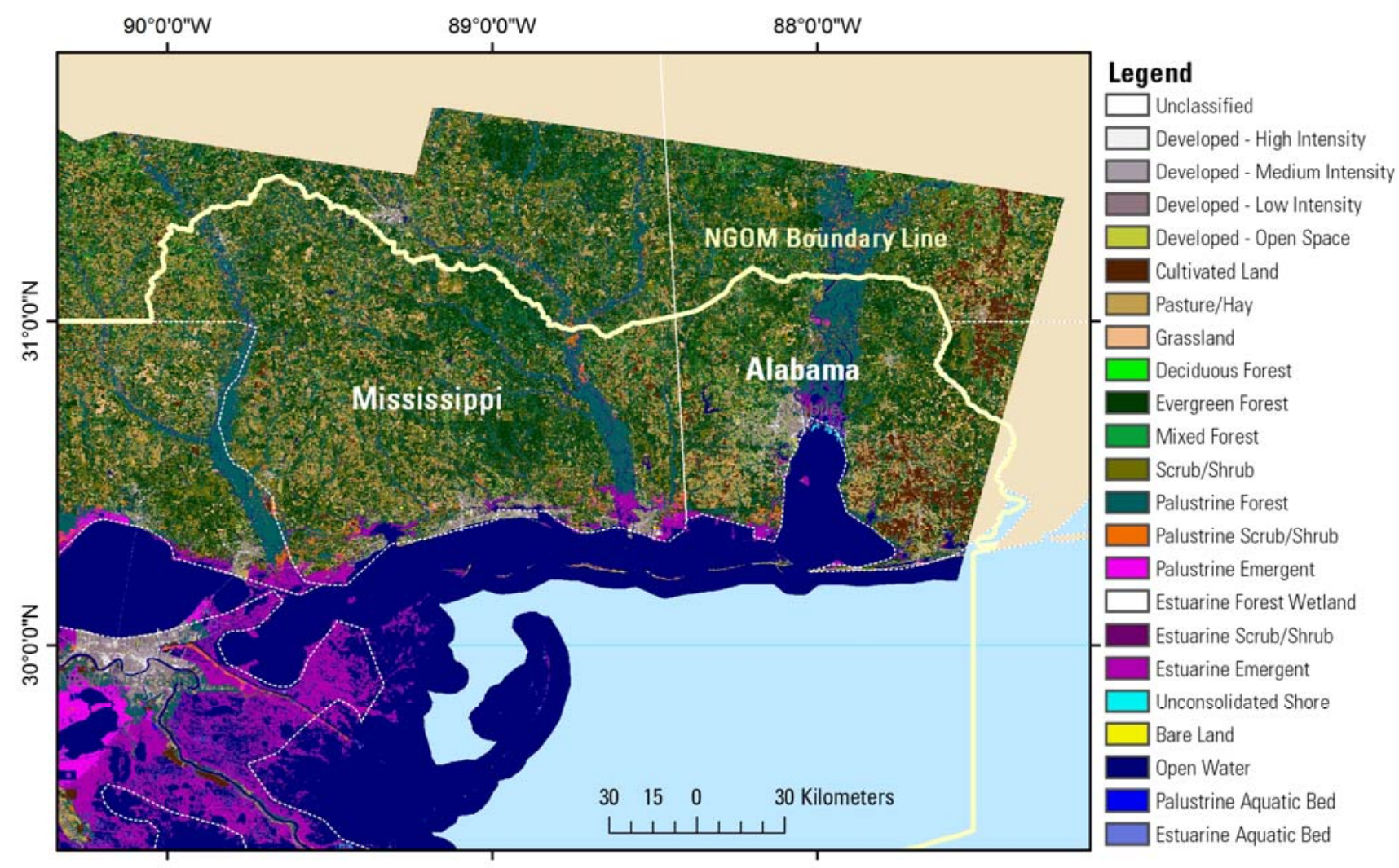

Figure 4. National Oceanic and Atmospheric Administration (NOAA) Coastal-Change and Analysis Program (C-CAP) 2006 post-Hurricane Katrina data coverage for the Alabama and Mississippi study region. NGOM, Northern Gulf of Mexico Ecosystem Change and Hazard Susceptibility Project.

\section{Ancillary Data}

High-resolution land-cover mapping requires multiple data inputs, particularly satellite training data. Therefore, an important goal of this assessment was to determine the availability of ancillary data and potential training datasets within the AL-MS study region. Coastal monitoring in Mississippi and Alabama is sparse. Individual entities may have conducted habitat surveys or vegetation transects, but 
we were unable to find any recent or consistent coastal-monitoring program within either State. The Mississippi Department of Marine Resources intends to establish monitoring sites and protocols for their Coastal Preserve Program but has not yet determined funding level or scope (J. Clark, Coastal Preserve Program, Mississippi Department of Marine Resources, written comm., July 1, 2008).

Elevation data are an important ancillary dataset for LULC-data production. The coastal counties of both Alabama and Mississippi have Lidar-derived 3-m digital-elevation model (DEM) data. The data are available via the USGS National Map (http://seamless.usgs.gov/).

The Fish and Wildlife Service National Wetlands Inventory (NWI) is produced by handdigitization of wetland features from orthophotography. The AL-MS NWI datasets often have additional upland areas classified. Data for 1955, 1979, and 1988 exist for the State of Alabama. Currently, a 2001-02 NWI dataset for coastal Alabama is in production, and ground-truthing was conducted for this mapping effort (J. Dugas, IAP World Services, Inc., written comm., July 29, 2008). Only a 1996 NWI dataset exists for the State of Mississippi (http://www.fws.gov/nwi/). 
Table 1. Land-use and land-cover (LULC) and ancillary data for the State of Alabama.

\begin{tabular}{|c|c|c|c|c|}
\hline Dataset Name & Date & Extent & Source Imagery & URLs/Notes \\
\hline \multirow{4}{*}{$\begin{array}{l}\text { National Oceanic and } \\
\text { Atmospheric Adminstration } \\
\text { (NOAA) Coastal-Change } \\
\text { Analysis Program (C-CAP) }\end{array}$} & 1996 & Coastal AL & Landsat TM & \multirow{4}{*}{$\begin{array}{l}\text { http://www.csc.noaa.gov/crs/lca/cc } \\
\text { ap.html }\end{array}$} \\
\hline & $2001 *$ & Coastal AL & Landsat TM & \\
\hline & 2005 & Coastal AL & Landsat TM & \\
\hline & 2006 & Coastal AL & Landsat TM & \\
\hline \multirow{2}{*}{$\begin{array}{l}\text { Multi-Resolution Land } \\
\text { Characteristics (MRLC) } \\
\text { Consortium }\end{array}$} & 1992 & National & Landsat TM & \multirow{2}{*}{ http://www.mrlc.gov/ } \\
\hline & $2001 *$ & National & Landsat TM & \\
\hline \multirow{4}{*}{$\begin{array}{l}\text { Fish and Wildlife Service } \\
\text { (FWS) National Wetland } \\
\text { Inventory (NWI) }\end{array}$} & 1955 & Coastal AL & Aerial photography & \multirow{4}{*}{$\begin{array}{l}\text { http://nwi.fws.gov/, Data were } \\
\text { digitized and are distributed by the } \\
\text { USGS National Wetlands Research } \\
\text { Center (NWRC), } \\
\text { http://sabdata.cr.usgs.gov/ }\end{array}$} \\
\hline & 1979 & Coastal AL & Aerial photography & \\
\hline & 1988 & Coastal AL & Aerial photography & \\
\hline & 2001 & Coastal AL & Aerial photography & \\
\hline $\begin{array}{l}\text { US Geological Survey } \\
\text { (USGS) enhanced historic } \\
\text { land-use and land-cover } \\
\text { (LULC) datasets }\end{array}$ & 1973 & National & Aerial photography & http://pubs.usgs.gov/ds/2006/240/ \\
\hline $\begin{array}{l}\text { U.S. Geological Survey } \\
\text { (USGS) Digital Elevation } \\
\text { Model (DEM), The National } \\
\text { Map }\end{array}$ & 2007 & Coastal AL & Lidar & http://seamless.usgs.gov/ \\
\hline
\end{tabular}

*The 2001 NOAA C-CAP and 2001 MRLC land-cover datasets are the same product, with the C-CAP dataset having additional nested coastal-habitat categories not included in the MRLC data layer. 
Table 2. Land-use and land-cover (LULC) and ancillary data for the State of Mississippi.

\begin{tabular}{|c|c|c|c|c|}
\hline Dataset Name & Date & Extent & Source Imagery & \\
\hline \multirow{4}{*}{$\begin{array}{l}\text { National Oceanic and } \\
\text { Atmospheric Administration } \\
\text { (NOAA) Coastal-Change } \\
\text { Analysis Program (C-CAP) }\end{array}$} & 1996 & Coastal MS & Landsat TM & \multirow{4}{*}{ http://www.csc.noaa.gov/crs/lca/ccap.html } \\
\hline & $2001 *$ & Coastal MS & Landsat TM & \\
\hline & 2005 & Coastal MS & Landsat TM & \\
\hline & 2006 & Coastal MS & Landsat TM & \\
\hline \multirow{4}{*}{$\begin{array}{l}\text { Mississippi Automated } \\
\text { Resource Information } \\
\text { System (MARIS) }\end{array}$} & $\begin{array}{l}1972- \\
75 * *\end{array}$ & Statewide & Aerial photography & \multirow{4}{*}{$\begin{array}{l}\text { Web site contains two PDF files } \\
\text { describing datasets within their holdings, } \\
\text { http://www.maris.state.ms.us/ }\end{array}$} \\
\hline & 1993 & Statewide & Landsat TM & \\
\hline & 1999 & Statewide & Landsat TM & \\
\hline & 2003 & Coastal MS & Landsat TM & \\
\hline \multirow{2}{*}{$\begin{array}{l}\text { Mississippi Department of } \\
\text { Transportation (MDOT) }\end{array}$} & 1990 & Coastal MS & Landsat TM & \multirow{2}{*}{$\begin{array}{l}\text { http://www.isprs.org/commission1// } \\
\text { /proceddings02/paper/00085.pdf } \\
\text { (Accessed on September 18, 2008) }\end{array}$} \\
\hline & 2000 & Coastal MS & Landsat TM & \\
\hline \multirow{2}{*}{$\begin{array}{l}\text { Multi-Resolution Land } \\
\text { Characteristics (MRLC) } \\
\text { Consortium }\end{array}$} & 1992 & National & Landsat TM & \multirow{2}{*}{ http://www.mrlc.gov/ } \\
\hline & $2001 *$ & National & Landsat TM & \\
\hline \multirow{3}{*}{$\begin{array}{l}\text { Mississippi Department of } \\
\text { Environmental Quality } \\
\text { (MSDEQ), Office of } \\
\text { Geology }\end{array}$} & 1956 & Coastal MS & Aerial photography & \multirow{3}{*}{$\begin{array}{l}\text { Scanned Fish and Wildlife Service maps } \\
\text { from } 1956 \text { and } 1978-82 \text {, and digitized } \\
1992 \text { land-use information from aerial } \\
\text { photography }\end{array}$} \\
\hline & $1978-82$ & Coastal MS & Aerial photography & \\
\hline & 1992 & Coastal MS & Aerial photography & \\
\hline $\begin{array}{l}\text { Fish and Wildlife Service } \\
\text { (FWS) National Wetland } \\
\text { Inventory (NWI) }\end{array}$ & 1996 & Coastal MS & Aerial photography & $\begin{array}{l}\text { http://nwi.fws.gov/, Data were digitized } \\
\text { and are distributed by the USGS National } \\
\text { Wetlands Research Center (NWRC), } \\
\text { http://sabdata.cr.usgs.gov/ }\end{array}$ \\
\hline $\begin{array}{l}\text { Grand Bay National } \\
\text { Estuarine Research Reserve } \\
\text { (GBNERR) }\end{array}$ & 2002 & $\begin{array}{l}\text { GBNERR } \\
\text { boundary }\end{array}$ & QuickBird & http://grandbaynerr.org/ \\
\hline $\begin{array}{l}\text { US Geological Survey } \\
\text { (USGS) enhanced historic } \\
\text { land-use and land-cover } \\
\text { (LULC) datasets }\end{array}$ & 1973-74 & National & Aerial photography & http://pubs.usgs.gov/ds/2006/240/ \\
\hline $\begin{array}{l}\text { U.S. Geological Survey } \\
\text { (USGS) Digital Elevation } \\
\text { Model (DEM), The National } \\
\text { Map }\end{array}$ & 2007 & Coastal MS & Lidar & http://seamless.usgs.gov/ \\
\hline
\end{tabular}

* The 2001 NOAA C-CAP and 2001 MRLC land-cover datasets are the same product, with the C-CAP dataset having additional nested coastal-habitat categories not included in the MRLC data layer.

** The data were not obtained. It is possible the referenced data are the same data as the USGS historic LULC. 


\section{Priority Areas}

Final assessment of the AL-MS study region has determined that high-resolution land-cover mapping activities are minimal. There is interest by the land-use planning and resource-management communities in high-resolution land-cover data, particularly for mapping coastal wetlands and invasive species and for use in urban planning. Areas of study that can benefit from additional research include (1) refinement of wetland vegetation classes to identify saline, brackish, and fresh marsh for northern Gulf of Mexico coastal wetlands, (2) identification of invasive species or species of special concern (endangered or threatened species), (3) urban-growth mapping for emergency response, and (4) automated parameters for high-resolution mapping procedures. Partners and collaborators for these studies can be found within all levels of the government sector, as well as in university and nonprofit entities. Several specific locations and project scopes are provided below as examples of studies that could yield advantageous results.

\section{Grand Bay Reserve}

The Grand Bay Reserve is a combined State-Federal partnership of lands located in eastern Mississippi, on the Mississippi-Alabama border. It is actually two management units, the Grand Bay National Estuarine Research Reserve (GBNERR) managed by the Mississippi Department of Marine Resource (DMR) [with designation by the U.S Department of Commerce's National Oceanic and Atmospheric Administration (NOAA)], and the Grand Bay National Wildlife Refuge, managed by the Fish and Wildlife Service (FWS). For simplicity, the combined wildlife refuge and the estuarine reserve are called the Grand Bay Reserve.

In 2002, the GBNERR had a contractor create a classified habitat map using 2002 QuickBird imagery. The GBNERR staff collected ground-truth data for 100 stratified random locations across the reserve (this occurred in subsequent years, estimated by staff as during 2005). They collected notes on 
species present, diameter at breast height (dbh), canopy cover, and other notable features. They are willing to share these data for a potential land-cover change analysis. The classification covers the entire GBNERR boundary but not the neighboring wildlife refuge (to the north).

GBNERR managers have been concerned about the presence of invasive species, particularly Cogon grass (Imperata cylindrical) and Chinese tallow (Triadica sebifera) on reserve lands. When populations are encountered in the field, the managers have made note and maintained a database with their location, with the desire to gain more understanding on the presence and distribution of these species.

The GBNERR has been funded by NOAA to conduct limited vegetation sampling within the reserve and refuge boundary. This project may be compatible with ground-truthing and (or) postprocessing accuracy assessment.

\section{Gulf Islands National Seashore}

The Gulf Islands National Seashore (GUIS) is a series of barrier-island and coastal land tracts managed by the National Park Service (NPS). Currently, GUIS has very limited vegetation monitoring but has conducted transects in the past in select areas. Since the majority of GUIS lands are located on barrier islands, the habitats are dynamic, thereby limiting the interpretation of vegetation data. There are vegetation transects being monitored by various university partners that may be useful in land-cover analyses, but these may be limited in scope and temporal frequency. NPS staff welcome collaboration toward an automated or more efficient method of monitoring their dynamic environments and are willing to share whatever data they have. They may also be able to supply limited funds to university partners to conduct vegetation surveys for the land-cover classification process or accuracy assessment. Petit Bois Island (within GUIS), located immediately south of the GBNERR, may be included as a pilot study for combining high-resolution land-cover data with Lidar bare-earth and first-surface data with 
field-based surveys to gain a greater understanding of the ability of these technologies for fine-scale vegetation mapping.

\section{City of Mobile}

The City of Mobile, the third most populous city in the Southern United States, is located on the Gulf of Mexico coast and therefore needs to respond to immediate threats of hurricanes, as well as the long-term threat of sea-level rise. High-resolution land-cover mapping can be a valuable tool for urban planning, particularly in natural disaster or emergency response and long-term planning for sea-level rise. Land-use managers would benefit from the development of automated procedures for urban landcover mapping so that the city can obtain the most up-to-date data for emergency response, land-use planning, and environmental monitoring. In addition, the Mobile Bay National Estuarine Program (MBNEP) conducts water-quality monitoring within Mobile Bay. A high-resolution land-cover dataset may assist this program in understanding the impact of the urban watershed on water-quality issues within the bay.

\section{Summary}

High-resolution land-cover mapping projects within the AL-MS study region are minimal. Moderate-resolution land-cover data and ancillary data exist for this region, but the area is lacking in significant monitoring data that can be used as ground-truthing or satellite training data. The region has several study areas that would benefit from high-resolution mapping, particularly in the naturalresources sector of environmental monitoring, invasive-species mapping, and wetland mapping, as well as the urban-planning sector on land-use planning and emergency response. Significant contributions of a high-resolution land-cover mapping program could be in the (1) development of automated methods 
and protocols for classification, (2) refinement of coastal-wetland classifications, and (3) identification of invasive species.

\section{References Cited}

Fritz, L.W., 1996, The era of commercial earth observation satellites: Photogrammetric Engineering and Remote Sensing v 62, p. 39-45.

Johnson, Adam, Truax, D.D., O’Hara, C.G., and John Cartwright, 2002, Remote sensing, GIS, and land use and land cover mapping along the I-10 corridor, in Pecora 15/Land Satellite Information Conference, $4^{\text {th }}$, Denver, CO, November 10-14, 2002, Proceedings, International Society for Photogrammetry and Remote Sensing.

Meyer-Arendt, K.J. and Yassin, Barbara,1994, Mississippi coastal geology and regional marine study 1990-1994, Volume 3, Land use/land cover changes in mainland coastal Mississippi, 1950s to 1992: Mississippi Department of Environmental Quality, Office of Geology, Jackson, MS, 409 p.

Oivanki, S.M., Meyer-Arendt, K.J., Yassim, Barbara, 1995, Analysis of land use and land cover changes on the Mississippi coast: 1950s-1992: Gulf Coast Association of Geological Societies, Transactions, v. 45, p. 467-473.

Office of Science and Technology Policy, 2003, U.S. Commercial Remote Sensing Policy, Office of Science and Technology Policy, Executive Office of the President, 7 p., http://crssp.usgs.gov/pdfs/factsheet.pdf, accessed on October 30, 2008. 


\section{Appendix}

\section{Appendix A: Grand Bay National Estuarine Research Reserve 2002 Habitat}

\section{Map Vegetation Class Descriptions}

Unclassified: Area outside the geographic scope of the analysis.

Beach/exposed sand: Areas dominated by exposed sandy sediment. These areas may include marsh species as well as the shrub species typically occurring in high-marsh areas (described below).

Freshwater marsh/aquatic vegetation: Freshwater marsh and pond areas, including nontidal marsh graminoids, aquatic plants and forbs growing in inundated areas. Some typical species include Sagittaria lancifolia, Juncus effusus, Cladium jamaicense, and Peltandra virginica.

High marsh: Marsh areas dominated by Spartina patens. Other species present in these areas include Scirpus olneyi, Spartina cynosuroides, Distichlis spicata, and shrub species Baccharis halimifolia and Iva frutescens.

Industrial facilities: Commercial and industrial facilities near the boundary of the subject site. Intermediate marsh: Marsh areas dominated by Juncus roemerianus. These areas may include other marsh species (Distichlis spicata, among others) and are characterized by lower water levels than the tidal/inundated-marsh class.

Roads/driveways: Areas consisting primarily of concrete, asphalt, gravel, and oyster or clam shell paving material.

Salt pan: Areas of exposed sandy sediment dominated by Distichlis spicata and Salicornia bigelovii. These areas may also include Spartina spartinae and other graminoids and forbs. 


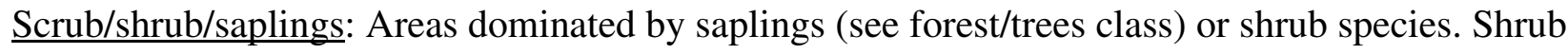
species in the study area typically include Myrica cerifera, Baccharis halimifolia, Iva frutescens, Ilex coriacea, Ilex glabra, and Ilex vomitoria.

Tidal/inundated marsh: Marsh areas characterized by daily or constant inundation, primarily consisting of Spartina alterniflora, Juncus roemerianus, and Distichlis spicata.

Forest/trees: Individual trees and areas of continuous forest. Typical species include Pinus elliottii, Taxodium distichum, Sapium sebiferum, Quercus virginiana and Taxodium ascendens.

Upland grasses/agriculture/residential: Areas primarily consisting of nonwetland graminoid species or cultivated grasses. In some cases, mowed or otherwise maintained wetland and marsh species are present in these areas.

Water: Water areas, including open estuarine and fresh-water as well as isolated ponded areas within other land-cover types.

Wet Herbaceous: Graminoid and forb-dominated habitat, characterized by saturated soils or limited surface water. Areas with extensive surface-water coverage are classified as marsh classes, aquatic vegetation, or water, though some of the same plant species may be present. Some of these areas are in pine savannas and represent the herbaceous layer where there is no canopy cover. 